\title{
Streptococcus mutans Dental Caries among Patients Attending Debre Berhan Referral Hospital, Ethiopia
}

\section{Demissew Shenkute and Tsegahun Asfaw*}

Department of Medical Laboratory Science, College of Medicine, Debre Berhan University, Debre Berhan, Ethiopia

"Corresponding author: Tsegahun Asfaw, Department of Medical Laboratory Science, College of Medicine, Debre Berhan University, Debre Berhan, Ethiopia, Email: tsegahun.asfaw12@gmail.com

Received date: November 20, 2018; Accepted date: December 28, 2018; Published date: January 4, 2019

Copyright: $@ 2019$ Shenkute D, et al. This is an open-access article distributed under the terms of the Creative Commons Attribution License, which permits unrestricted use, distribution, and reproduction in any medium, provided the original author and source are credited.

\begin{abstract}
Background: Dental caries is an irreversible microbial disease of the calcified tissues of the teeth. Streptococcus mutans is a bacterial resident of the oral cavity and is considered to be the principal etiological agent of dental caries in humans. Therefore, the aim of this study was to determine the prevalence and risk factors associated with Streptococcus mutans dental caries.
\end{abstract}

Methods: A cross sectional study was conducted among patients who attended Debre Berhan referral hospital dental clinic. Patient's demographic and clinical information was collected by using pre-tested questionnaire. Dental plaques from all patients was picked up by forceps and suspended in to phosphate-buffered saline for further Streptococcus mutans identification.

Result: From a total of 115 study participants $56(48.7 \%)$ and 59 (51.3\%) were males and females respectively. The overall prevalence of Streptococcus mutans was $79(68.7 \%)$ among patients with dental caries. participants 25 $(21.7 \%)$ had gem bleeding and $47(40.9 \%)$ of the participants had previous tooth decay.

Conclusion: In this study, again Streptococcus mutans is the common public health problem among dental caries patients. Drinking soft drinks, oral debris and gingival index were the associated risk factor for dental caries of Streptococcus mutans.

Keywords: Streptococcus mutans; Dental caries; Ethiopia

\section{Introduction}

Dental plaque is an adherent deposit of bacteria and their products, which forms as a white greenish or even yellow film on all tooth surfaces. Dental plaque accumulates naturally at stagnant or retentive sites formed after one to two days with no oral hygiene [1]. Dental caries is the single most prevalent and costly infectious disease worldwide, affecting more than $90 \%$ of the population in the US. The development of dental cavities requires the colonization of the tooth surface by acid producing bacteria, such as Streptococcus mutans, in conjunction with the frequent ingestion of a cariogenic high sucrose diet, the substrate for acid and glucan production by organisms. The elevated amounts of acid and glucans modulate the establishment of cariogenic organisms within tightly adherent biofilms known as dental plaque [2]. Streptococcus mutans is one of the major etiological factors of dental caries. Tooth surfaces colonized with $S$. mutans are at a higher risk for developing caries [3]. Dental caries is an irreversible microbial disease of the calcified tissues of the teeth, which is characterized by demineralization of the inorganic portion and destruction of the organic substance of the tooth, which often leads to cavitation. Dental caries is a multifactorial disease, which is caused by host, agent, and environmental factors [4]. Streptococcus mutans are gram positive cocci bacteria. These facultative anaerobes are commonly found in the human oral cavity, and are a major contributor of tooth decay. $S$. mutans grow at temperatures between $18^{\circ} \mathrm{C}-40^{\circ} \mathrm{C}$. Streptococcus mutans are a cariogenic microorganism that breaks down sugar for energy and produces an acidic environment, which dematerialize the superficial structure of the tooth. The result of the conversion disintegrates the coating of the tooth then later dissolves the Calcium molecule creating a hole $[5,6] . S$. mutans can be isolated from individuals either with or without a history of caries, but the development of dental caries dependent on the bacterial load strain variation of S.mutans including, acid-utility, biofilm-formation potential, and production of glucans $[7,8]$.

\section{Materials and Methods}

\section{Study area and period}

The study was conducted at Debre Berhan referral hospital, which is located around $130 \mathrm{~km}$ away from Addis Ababa. The study was conducted from March, 2017 to August, 2018.

\section{Study design}

A cross sectional study was conducted.

\section{Inclusion and exclusion criteria}

All patients attending dental clinic of Debre Berhan referral hospital with clinical manifestation of dental caries and who are volunteer and able to give sample were included. Patients who are taking antibiotics in the last 30 day were excluded. 
Page 2 of 7

\section{Sample size and sampling technique}

The sampling technique was based on convenient sampling method. The sample size was all patients with clinical manifestation of dental caries who were visited Debre Berhan referral hospital dental clinic and fulfill inclusion criteria.

\section{Data collection methods}

Patient's socio demographic and clinical information was collected by using pre-tested questionnaire. All study participants was examined by dental doctor. Dental plaques from all patients were picked up through forceps (probe) and transferred into $2 \mathrm{ml}$ of sterile tube containing phosphate-buffered saline and processed immediately after collection in Debre Berhan university microbiology laboratory [9].

\section{Isolation and identification of $S$. mutans}

The dental plaque suspension was vortexed for $30 \mathrm{~s}$ for content homogenization. Then a volume of $100 \mu \mathrm{l}$ was spread onto Mitissalivaris (MS-agr) by using sterile cotton swab and incubated in 5\% $\mathrm{CO}_{2}$ for 48 hours at $37^{\circ} \mathrm{C}$. A colony count of more than 250 colonies (104 cells $/ \mathrm{ml}$ ) was considered as positive samples. Small colony was subculture on the surface of blood-agar plates for further identification. A gram positive cocci, alpha hemolytic on blood agar, catalase negative mannitol, and lactose fermenters was considered $S$. mutans $[1,10]$.

\section{Data entry and analysis}

Data was edited, cleaned and checked for its completeness and was entered SPSS version 16 for analysis. Patients' Socio-demographic and clinical characteristics were described by using descriptive statistics. Bivariate and multivariate logistic regression analysis was done to identify the risk factors and p-value less than 0.05 was taken as statistically significant.

\section{Ethical consideration}

Ethical clearance was obtained from Debre Berhan University Ethical Review Board. Letter of permission was secured from Debre Berhan referral Hospital clinical director managements. Written informed consent and assent was obtained from the study participants. Any information concerning the patients was kept confidential and patients with positive result were communicated.

\section{Quality control}

To assure the quality of the data generated during the study, standard operating procedures were followed during media preparation and other laboratory procedures. Sterility check was performed to avoid the possibility of contamination. All reagents was checked for their expiry date and prepared according to the manufacturer's instruction.

\section{Results}

Among of 115 study participants, the overall prevalence of dental caries of Streptococcus mutans was 79 (68.7\%).

\section{Socio-demographic characteristics of the of the participants}

Among 115 participants, 56 (48.7\%) were males and 59 (51.3\%) were females. The mean age of the participants was 32.67 years with standard deviation $(\mathrm{SD}=1.48) .64(55.7 \%)$ and $51(44.3 \%)$ of the participants were come from urban and rural area respectively. Regarding occupation 17 (14.8\%) of them were housewife followed by farmer $13(11.3 \%)$. In terms of educational status, majority of the residents, $34(49.3 \%)$ has completed grade 12 , as shown in Table 1.

\begin{tabular}{|c|c|c|c|c|}
\hline \multicolumn{2}{|c|}{ Socio- demographic characteristics } & \multicolumn{2}{|c|}{ Culture result for Streptococcus mutans } & \multirow{3}{*}{$\begin{array}{l}\text { Total NO (\%) } \\
56(48.7)\end{array}$} \\
\hline & & Positive NO (\%) & Negative NO (\%) & \\
\hline \multirow[t]{2}{*}{ Sex } & Male & $43(37.4)$ & $13(11.3)$ & \\
\hline & Female & $36(31.3)$ & $23(20.0)$ & 59 (51.3) \\
\hline \multirow[t]{2}{*}{ Place of residence } & Urban & $41(35.7)$ & $23(20.0)$ & $64(55.7)$ \\
\hline & Rural & $38(33.0)$ & $13(11.3)$ & $51(44.3)$ \\
\hline \multirow[t]{7}{*}{ Occupation } & Farmer & $11(9.6)$ & $2(1.7)$ & $13(11.3)$ \\
\hline & Merchant & $6(5.2)$ & $5(4.3)$ & $11(9.6)$ \\
\hline & Employed & $10(8.7)$ & $7(6.1)$ & $17(14.8$ \\
\hline & Unemployed & $3(2.6 \%)$ & $1(0.9)$ & $4(3.5)$ \\
\hline & Housewife & $11(9.6)$ & $6(5.2)$ & $17(14.8)$ \\
\hline & Driver & $1(0.9)$ & $0(0)$ & $1(0.9)$ \\
\hline & Other & $37(32.2)$ & $15(13.0)$ & $52(45.2)$ \\
\hline \multirow[t]{2}{*}{ Educational status } & Illiterate & $36(31.3)$ & $10(8.7)$ & $46(40.0)$ \\
\hline & Read \&write only & $2(2.9)$ & $3(4.3)$ & $5(7.2)$ \\
\hline
\end{tabular}


Citation: Shenkute D, Asfaw T (2019) Streptococcus mutans Dental Caries among Patients Attending Debre Berhan Referral Hospital, Ethiopia. J Bacteriol Parasitol 10: 350. doi:10.4172/2155-9597.1000350

Page 3 of 7

\begin{tabular}{|l|l|l|l|l|}
\hline \multirow{2}{*}{} & $1-4$ grade & $5(7.2)$ & $5(7.20)$ & $10(14.5)$ \\
\cline { 2 - 5 } & $5-8$ grade & $7(10.1)$ & $1(1.4)$ & $8(11.6)$ \\
\cline { 2 - 5 } & $9-12$ grade & $7(10.1)$ & $5(7.2)$ & $12(17.4)$ \\
\cline { 2 - 5 } & Above 12 & $22(31.9)$ & $12(17.4)$ & $34(49.3)$ \\
\hline
\end{tabular}

\section{Knowledge and practice on tooth cleaning habit of the respondents}

From 115 participants $73(63.5 \%)$ were cleaned their teeth and among these $73(63.5 \%), 40(54.8 \%)$ were used tooth stick and tooth brush respectively. From respondents who cleaned their teeth more than half of them were cleaned their teeth in sideway (horizontally) and also most of the participants were cleaned their tooth after meal and morning only. Very few were cleaned their teeth morning and before going to bed as shown in Table 2 .

\begin{tabular}{|c|c|c|c|c|}
\hline \multicolumn{2}{|c|}{ Knowledge and practice on oral health } & \multicolumn{3}{|c|}{ Culture result for S. mutans } \\
\hline & & \multirow{2}{*}{$\begin{array}{l}\text { Positive NO (\%) } \\
47(40.9)\end{array}$} & \multirow{2}{*}{$\begin{array}{l}\text { Negative NO (\%) } \\
26(22.6)\end{array}$} & \multirow{2}{*}{$\begin{array}{l}\text { Total NO (\%) } \\
73(63.5)\end{array}$} \\
\hline Habit of cleaning teeth & Yes & & & \\
\hline & No & $32(27.8)$ & $10(8.7)$ & $42(36.5)$ \\
\hline \multirow{4}{*}{$\begin{array}{l}\text { Materials used to clean } \\
\text { teeth }\end{array}$} & Tooth Stick & $28(38.4)$ & $12(16.4)$ & $40(54.8)$ \\
\hline & Charcoal & $1(1.4)$ & $2(2.7)$ & $3(4.1)$ \\
\hline & Tooth brush \& rinse with water & $9(12.3)$ & $8(11.0)$ & $17(23.3)$ \\
\hline & Others & $9(12.3)$ & $4(5.5)$ & $13(17.8)$ \\
\hline \multirow{5}{*}{$\begin{array}{l}\text { Frequency of cleaning } \\
\text { teeth }\end{array}$} & Once a day & $22(30.1)$ & $4(5.5)$ & $26(35.6)$ \\
\hline & After each meal & $2(2.7)$ & $3(4.1)$ & $5(6.8)$ \\
\hline & Before and after each meal & $2(2.7)$ & $3(4.1)$ & $5(6.8)$ \\
\hline & More than once a day & $3(4.1)$ & $4(5.5)$ & $7(9.6)$ \\
\hline & Irregularly & $18(24.7)$ & $12(16.4)$ & $30(41.1)$ \\
\hline \multirow[t]{4}{*}{ Way of cleaning teeth } & Top to bottom & $6(8.2)$ & $5(6.8)$ & $11(15.1)$ \\
\hline & Side way & $23(31.5)$ & $10(13.7)$ & $33(45.2)$ \\
\hline & Mixed & $16(21.9)$ & $11(15.1)$ & $27(37.0)$ \\
\hline & Circular & $2(2.7)$ & $0(0.0)$ & $2(2.7)$ \\
\hline \multirow[t]{5}{*}{ Time of brushing teeth } & Morning only & $13(17.8)$ & $10(13.7)$ & $23(31.5)$ \\
\hline & After meal & $16(21.9)$ & $8(11.0)$ & $24(32.9)$ \\
\hline & Before meal & $3(4.1)$ & $0(0.0)$ & $3(4.1)$ \\
\hline & Before going to bed & $2(2.7)$ & $0(0.0)$ & $2(2.7)$ \\
\hline & Irregular & $11(15.1)$ & $8(11.0)$ & $19(26.1)$ \\
\hline
\end{tabular}

Table 2: Knowledge and practice on tooth cleaning habit of patients attending dental clinic of Debre Berhan referral hospital from March 2017 to April 2018.

\section{Associated risk factor for dental caries}

Sixteen (13.9\%) and 8 (7.0\%) of the study participants had a habit of drinking alcohol and smoking cigarette respectively. Twenty eight (24.3\%) of the participants had a habit of chewing chat. Seventy two $(62.6 \%)$ of the participants had a habit of taking sweet in take or food.
Twenty two (30.6\%) of the participants were taking sweet intake irregularly. Eighty one (70.4\%) of the participants had a habit of taking soft drink and significantly associated with $S$. mutans dental caries $(\mathrm{p}=0.01)$ as shown in Table 3 . 
Citation: Shenkute D, Asfaw T (2019) Streptococcus mutans Dental Caries among Patients Attending Debre Berhan Referral Hospital, Ethiopia. J Bacteriol Parasitol 10: 350. doi:10.4172/2155-9597.1000350

Page 4 of 7

\begin{tabular}{|c|c|c|c|c|c|}
\hline \multicolumn{2}{|l|}{ Associated risk factor } & \multicolumn{3}{|c|}{ Culture result Streptococcus mutans } & \multirow{3}{*}{$\begin{array}{l}\text { p- value } \\
0.24\end{array}$} \\
\hline & & Positive No (\%) & Negative No (\%) & Total No (\%) & \\
\hline \multirow[t]{2}{*}{ Habit of drinking alcohol } & Yes & $13(11.3)$ & $3(2.6)$ & $16(13.9)$ & \\
\hline & No & $66(57.4)$ & $33(28.7)$ & $99(86.1)$ & \\
\hline \multirow{3}{*}{$\begin{array}{l}\text { Frequency of drinking } \\
\text { alcohol }\end{array}$} & Always & $0(0.0)$ & $1(6.2)$ & $1(6.2)$ & \multirow[t]{3}{*}{0.10} \\
\hline & Sometimes & $6(37.5)$ & $1(6.2)$ & $7(43.8)$ & \\
\hline & Rarely & $7(43.8)$ & $1(6.2)$ & $8(50)$ & \\
\hline \multirow[t]{2}{*}{ Habit of smoking cigarette } & Yes & $8(7)$ & $1(0.9)$ & $9(7.8)$ & \multirow[t]{2}{*}{0.17} \\
\hline & No & $71(61.7)$ & $35(30.4)$ & $106(92.2)$ & \\
\hline \multirow[t]{3}{*}{ Frequency of smoking cigarette } & Regularly & $5(55.6)$ & $0(0.0)$ & $5(55.6)$ & \multirow[t]{3}{*}{0.32} \\
\hline & Occasionally & $3(33.3)$ & $0(0.0)$ & $3(33.3)$ & \\
\hline & Rarely & $0(0.0)$ & $1(11.1)$ & $1(11.1)$ & \\
\hline \multirow[t]{2}{*}{ Habit chewing chat } & Yes & $23(20)$ & $5(4.3)$ & $28(24.3)$ & \multirow[t]{2}{*}{0.08} \\
\hline & No & $56(48.7)$ & $31(27.0)$ & $87(75.7)$ & \\
\hline \multirow[t]{3}{*}{ Frequency of chewing chat } & Regularly & $8(28.6)$ & $1(3.6)$ & $9(32.6)$ & \multirow[t]{3}{*}{0.40} \\
\hline & Occasionally & $12(42.9)$ & $2(7.1)$ & $14(50.0)$ & \\
\hline & Rarely & $3(10.7)$ & $2(7.1)$ & $5(17.9)$ & \\
\hline \multirow[t]{2}{*}{ Habit of taking sweet intakes or food } & Yes & $46(40)$ & $26(22.6)$ & $72(62.6)$ & \multirow[t]{2}{*}{0.15} \\
\hline & No & $33(28.7)$ & $10(8.7)$ & $43(37.4)$ & \\
\hline \multirow[t]{6}{*}{ Kind of sweet intake } & Chocolate & $0(0.0)$ & $3(4.2)$ & $3(4.2)$ & \multirow[t]{5}{*}{0.20} \\
\hline & Candy & $1(1.4)$ & $1(1.4)$ & $2(2.8)$ & \\
\hline & Sugar cane & $6(8.3)$ & $3(4.2)$ & $9(12.5)$ & \\
\hline & Sugared coffee & $21(29.1)$ & $8(11.1)$ & $29(40.3)$ & \\
\hline & Sugared tea & $12(16.7)$ & $9(12.5)$ & $21(29.2)$ & \\
\hline & Others & $6(8.3)$ & $2(2.8)$ & $8(11.1)$ & \\
\hline \multirow[t]{6}{*}{ Frequency of taking sweet intake } & Once a day & $13(18.1)$ & $3(4.2)$ & $16(22.2)$ & \multirow[t]{6}{*}{0.15} \\
\hline & After each meal & $8(11.1)$ & $1(1.4)$ & $9(12.5)$ & \\
\hline & More than once a day & $12(16.7)$ & $10(13.9)$ & $22(30.6)$ & \\
\hline & Irregularly & $12(16.7)$ & $10(13.9)$ & $22(30.6)$ & \\
\hline & Every other day & $1(1.4)$ & $1(1.4)$ & $2(2.8)$ & \\
\hline & Once time per week & $0(0.0)$ & $1(1.4)$ & $1(1.4)$ & \\
\hline \multirow[t]{2}{*}{ Habit of taking soft drinks } & Yes & $50(43.5)$ & $31(27.0)$ & $81(70.4)$ & \multirow[t]{2}{*}{0.01} \\
\hline & No & $29(25.2)$ & $5(4.3)$ & $34(9.6)$ & \\
\hline \multirow[t]{3}{*}{ Frequency of taking soft drink } & Regularly & $3(3.7)$ & $4(4.9)$ & $7(8.6)$ & \multirow[t]{3}{*}{0.26} \\
\hline & Occasionally & $28(34.6)$ & $12(14.8)$ & $40(49.4)$ & \\
\hline & Rarely & $19(23.5)$ & $15(18.5)$ & $34(42.0)$ & \\
\hline
\end{tabular}


Citation: Shenkute D, Asfaw T (2019) Streptococcus mutans Dental Caries among Patients Attending Debre Berhan Referral Hospital, Ethiopia.

Page 5 of 7

\begin{tabular}{|l|l|l|l|l|l|}
\hline \multirow{2}{*}{ Presence xerostomia } & Yes & $4(3.5)$ & $0(0.0)$ & $4(3.5)$ & 0.17 \\
\cline { 2 - 6 } & No & $75(65.2)$ & $36(31.3)$ & $111(100)$ \\
\hline Diabetes mellitus & Yes & $15(13.0)$ & $4(3.5)$ & $19(16.5)$ & 0.29 \\
\cline { 2 - 6 } & No & $64(55.7)$ & $32(27.8)$ & $96(83.5)$ & \\
\hline
\end{tabular}

Table 3: Associated risk factor for dental caries in patients attending dental clinic of Debre Berhan referral hospital from March 2017 to April 2018.

\section{Clinical data on oral health}

In this study, a total of 115 participants 25 (21.7\%) had gem bleeding and 47 (40.9\%) of the participants had previous tooth decay. Nearly more than half the respondents had oral debris covering not more than one third of the tooth surface. Only 42 (36\%) were free from oral debris. Oral debris has statistically significance association with $S$. mutans dental caries $(\mathrm{P}=0.022)$. Most of the participants $55(47.8 \%)$ had normal gingival index and 50 (43.5\%) had mild inflammation but only $1(0.9 \%)$ had sever inflammation. Gingival index has statistically significant association with $S$. mutans dental caries $(\mathrm{P}=0.002)$. Fifty eight $(50.4 \%)$ of the participant had no calculus index and 41 (35.7\%) had mild super gingival calculus. Only few $3(2.6 \%)$ had excessive supra and sub gingival calculus as shown in Table 4.

\begin{tabular}{|c|c|c|c|c|c|}
\hline \multicolumn{2}{|l|}{ Clinical finding } & \multicolumn{3}{|l|}{ Result } & \multirow{3}{*}{$\begin{array}{l}\text { p-value } \\
0.69\end{array}$} \\
\hline & & Positive No (\%) & Negative No (\%) & Total No (\%) & \\
\hline \multirow[t]{2}{*}{ Gem bleeding } & Yes & $18(15.7)$ & $7(6.1)$ & $25(21.7)$ & \\
\hline & No & $61(53.0)$ & $29(25.2)$ & $90(78.3)$ & \\
\hline \multirow[t]{2}{*}{ Previous tooth decay } & Yes & $35(30.4)$ & $12(10.4)$ & $47(40.9)$ & \multirow[t]{2}{*}{0.27} \\
\hline & No & $44(38.3)$ & $24(20.9)$ & $68(59.1)$ & \\
\hline \multirow[t]{4}{*}{ Oral debris } & No debris & $22(19.1)$ & $20(17.4)$ & $42(16.5)$ & \multirow[t]{4}{*}{0.022} \\
\hline & $\begin{array}{l}\text { Soft Debris covering not more than } 1 / 3 \text { of the } \\
\text { tooth surface }\end{array}$ & $47(40.9)$ & $14(12.2)$ & $64(53.0)$ & \\
\hline & $\begin{array}{l}\text { Soft debris covering more than } 1 / 3 \text { but not more } \\
\text { than } 2 / 3 \text { of the exposed tooth surface }\end{array}$ & $9(7.8)$ & $1(0.9)$ & $10(8.7)$ & \\
\hline & $\begin{array}{l}\text { soft debris covering more than two third of } \\
\text { exposed tooth surface }\end{array}$ & $1(0.9)$ & $1(0.9)$ & $2(1.8)$ & \\
\hline \multirow[t]{3}{*}{ Plaque index } & no plaque & $1(27.0)$ & $20(17.4)$ & $51(44.4)$ & \multirow[t]{3}{*}{0.23} \\
\hline & $\begin{array}{l}\text { plaque adhering to the free gingival margin which } \\
\text { cannot be seen by naked eye }\end{array}$ & $39(33.9)$ & $12(10.4)$ & $51(44.3)$ & \\
\hline & $\begin{array}{l}\text { moderate accumulation of deposits on the } \\
\text { gingival margin which can be seen with naked } \\
\text { eye }\end{array}$ & $9(7.8)$ & $4(3.5)$ & $13(11.3)$ & \\
\hline \multirow[t]{4}{*}{ Gingival index } & Normal & $30(26.1)$ & $25(21.7)$ & $55(47.8)$ & \multirow[t]{4}{*}{0.002} \\
\hline & mild inflammation & $40(34.8)$ & $10(8.7)$ & $50(43.5)$ & \\
\hline & Moderate inflammation & $9(7.8)$ & $0(0)$ & $9(7.8)$ & \\
\hline & sever inflammation & $0(0)$ & $1(0.9)$ & $1(0.9)$ & \\
\hline \multirow[t]{3}{*}{ Calculus index } & No calculus & $36(31.3)$ & $22(19.1)$ & $58(50.4)$ & \multirow[t]{3}{*}{0.24} \\
\hline & Mild super gingival calculus & $29(25.2)$ & $12(10.4)$ & $41(35.7)$ & \\
\hline & Moderate supra \& sub gingival calculus & $11(9.6)$ & $2(1.7)$ & $13(11.3)$ & \\
\hline
\end{tabular}




\begin{tabular}{|l|l|l|l|l|l|}
\hline & Excessive supra \& sub gingival calculus & $3(2.6)$ & $0(0)$ & $3(2.6)$ & \\
\hline
\end{tabular}

Table 4: Clinical finding in patients attending dental clinic of Debre Berhan referral hospital from March 2017 to April 2018.

\section{Class of tooth decay}

From the total 47 tooth decay cases, $21(44.7 \%)$ of them had class I followed by class II which was $17(36.2 \%)$ as shown in Table 5.

\begin{tabular}{|l|l|}
\hline Class of tooth decay & Frequency No (\%) \\
\hline Class I & $21(44.7)$ \\
\hline Class II & $17(36.2)$ \\
\hline Class III & $4(8.5)$ \\
\hline Class IV & $2(4.3)$ \\
\hline Class V & $3(6.4)$ \\
\hline Total & $47(100)$ \\
\hline
\end{tabular}

Table 5: Frequency of class of tooth decaying patients attending dental clinic of Debre Berhan referral hospital with culture results for $S$. mutans from March 2017 to April 2018.

\section{Discussions}

In Ethiopia, there is scarcity of data on Streptococcus mutans dental caries. In this study Streptococcus mutans dental caries is the major public health problem among patients attending dental clinic of Debre Berhan referral hospital. In this study, the prevalence of Streptococcus mutans dental caries was found to be (68.7\%) which is comparable with a study conducted in Brazil (68.5\%) [11], China (67.5\%) [12] and Srilanka (68.8\%) [13]. However, it was lower than study conducted in Qatar (85\%) [14], Saudi Arabia (80\%) [15]. It was higher than study conducted in other parties of Ethiopia particularly in Gondar (36.3\%) [15].The difference could be due to the difference in knowledge and practice on oral hygiene.

Habit of taking soft drink was found to be statistically significance association with Streptococcus mutans dental caries. This also supported by similar findings done in India and Zimbabwe respectively $[16,17]$. This also might be associated with acid production by cariogenic organism such as Streptococcus mutans that adherent to teeth as result of fermentation of soft drink. Later the enamel of tooth went to tooth decay.

In this study, the highest prevalence was seen in urban area 41 (35.7\%) than rural $38(33.0 \%)$. This finding was in agreements with a study done in Zimbabwe [17]. The possible reason for this also might be due to the habit of urban population taking soft drink and food.

Oral debris is a major risk factor for dental caries; that has statistically significant association with Streptococcus mutans dental caries than those who had no oral debris. This finding also confirms other findings [18]. Moreover; gingival index was significance association with Streptococcus mutans dental caries. Patients with gingival index were more likely to have dental caries of Streptococcus mutans. This also might be a good indicator of poor oral hygiene practices [19]. Because gingival index increase Streptococcus mutans colonization and in severe cases it involves loses of the enamel.
In this study drinking alcohol, smoking cigarette, taking soft intake, plaque index and calculus index and chewing chat has no significant association with Streptococcus mutans dental caries [20]. The reason for this discrepancy might be short data collection period and small number of the study population.

\section{Conclusions and Recommendations}

Dental caries of Streptococcus mutans is the common public health problem among patients attending at dental clinic of Debre Berhan referral hospital. Soft drinks, oral debris and gingival index were the associated risk factor for dental caries of Streptococcus mutans. Health education on oral hygiene, dietary habit and dental visit should be given to prevent and control Streptococcus mutans dental caries. Moreover, further studies using all diagnostic method should be done.

\section{Conflict of Interests}

The authors declare that they have no conflict of interests.

\section{Funding}

This work was not funded by any organization.

\section{Authors' Contributions}

DS performed the laboratory activities. DS analyzed the data. TA wrote the manuscript. All authors read and approved the final manuscript.

\section{Acknowledgments}

We would like to thank Debre Berhan University for giving this opportunity. We also thank staffs of dental clinic of Debre Berhan referral hospital for their help during data collection process. 
Citation: Shenkute D, Asfaw T (2019) Streptococcus mutans Dental Caries among Patients Attending Debre Berhan Referral Hospital, Ethiopia. J Bacteriol Parasitol 10: 350. doi:10.4172/2155-9597.1000350

Page 7 of 7

\section{References}

1. Nada HA, Al-Mudallal, Essam FA, Al-Jumaily, Nidhal AA, et al. (2008) Isolation and identification of mutan's streptococci bacteria from human dental plaque samples. J Al-Nahrain Univer 11: 98-105.

2. Catalán MA, Scott-Anne K, Klein MI, Koo H, Bowen WH, et al. (2011) Elevated Incidence of Dental Caries in a Mouse Model of Cystic Fibrosis Sample. PLoS One 6: e16549.

3. Pannu P, Gambhir R, Sujlana A (2013) Correlation between the salivary Streptococcus mutans levels and dental caries experience in adult population of Chandigarh, India. Eur J Dent 7: 191-195.

4. Kt S, Kmk M, N B, Jimson S, R S (2013) Dental Caries Vaccine - A Possible Option? J Clin Diag Res 7: 1250-1253.

5. Whiley RA, Beighton D (2013) "Streptococci and Oral Streptococci." BiteSized Tutorials. Np Web 1: 1.

6. Jav ND, Webed M, Chaudhry S, Butt S, Ijaz S, et. al (2013) Transmission of Streptococcus mutans from Mother to Child. Pak and Oral Dent J 32: 3.

7. Smith B, Pickard HM, Kidd EAM (1990) Why restore teeth? Pickard's manual of operative dentistry. (6thedtn), Oxford University Press, Oxford, England, UK.

8. Zhang L, Foxman B, Drake DR, Srinivasan U, Henderson J, et al. ( 2009) Comparative whole-genome analysis of Streptococcus mutans isolates within and among individuals of different caries status. Oral Microbial Immunol 24: 197-203.

9. Teresa CC, Franco EF, Patrícia A, José MM, Fernando ADA (2007) Detection of Streptococcus mutans and Streptococcus sobrinus in Denta Plaque Samples from Brazilian Preschool Children by Polymerase Chain Reaction. Bra Dent J 18: 329-333.

10. Cockerill FR, Wikler MA, Bush K, Dudley MN, Eliopoulos GM, et al (2011) Performance Standards for Antimicrobial Susceptibility Testing, Twenty-First Informational Supplement. Clin and Lab Stands Inst 31: 1 .
11. Costa SM, Vasconcelos M, Haddad JPA, Abreu MHN (2012) The severity of dental caries in adults aged 35 to 44 years residing in the metropolitan area of a large city in Brazil: a cross-sectional study. BMC Oral Health 12: 25.

12. Liu L, Zhang Y, Wu W, Cheng M, Li Y, et al. (2013) Prevalence and Correlates of Dental Caries in an Elderly Population in Northeast China. PLoS One 8: e78723.

13. Perera PJ, Abeyweera NT, Fernando MP, Warnakulasuriya TD, Ranathunga N (2012) Prevalence of dental caries among a cohort of preschool children living in Gampaha district, Sri Lanka: A descriptive cross sectional study. BMC Oral Health 12: 49.

14. Al-Darwish M, El Ansari W, Bener A (2014) Prevalence of dental caries among 12-14year old children in Qatar. Saudi Dent J 26: 115-125.

15. Ayele FA, Taye BW, Ayele TA, Gelaye KA (2013) Predictors of Dental caries among children 7-14 years old in Northwest Ethiopia: a community based cross-sectional study. BMC Oral Health 13: 7.

16. Sukhabogi J, Parthasarathi P, Anjum S, Shekar B, Padma C, et al. (2014) Dental Fluorosis and Dental Caries Prevalence among 12 and 15-YearOld School Children in Nalgonda District, Andhra Pradesh, India. Ann Med Health Sci Res 4: S245-S252.

17. Prasai Dixit L, Shakya A, Shrestha M, Shrestha A (2013) Dental caries prevalence, oral health knowledge and practice among indigenous Chepang school children of Nepal. BMC Oral Health 13: 20.

18. Mafuvadze BT, Mahachi L, Mafuvadze B (2013) Dental caries and oral health practice among 12 year old school children from low socioeconomic status background in Zimbabwe. Pan Afr Med J 14: 164.

19. T S, Kumar BS, Datta M, V T H, Nisha VA (2013) Prevalence, Severity and Associated Factors of Dental Caries in 3-6 Year Old Children. J Clin and Diag Res 7: 1789-1792.

20. Nobile CG, Fortunato L, Bianco A, Pileggi C, Pavia M (2014) Pattern and severity of early childhood caries in Southern Italy: a preschool-based cross-sectional study. BMC Public Health 14: 206. 